\title{
Exploring the Fit Between Corporate Social Responsibility (CSR) and Innovation in the Search for Corporate Reputation
}

\author{
Gideon Jojo Amos \\ Center for Innovation, Entrepreneurship, and Learning (CIEL) Research, Halmstad University, \\ Box 823, SE 30118 Halmstad, Sweden
}

\begin{abstract}
This paper aims to argue that the current wave of corporate social responsibility (CSR) and innovation concepts and guidelines lead to a mutually supportive and/or complementarities effect, i.e., strategic approaches to CSR and innovation increasingly strengthens companies' ability to draw on their relationships. This mutually supportive and/or complementarities effect can effectively address the multitude of CSR and innovation approaches that companies face. This conceptual paper uses stakeholder theory as a lens and, in turn, draws on organisational legitimacy and organisational learning to develop under which conditions claims of mutually supportive and/or complementarities effect will be considered. It provides evidence for the existence of a mutually supportive and/or complementarities effect as defining the characteristics of CSR and innovation approaches. The author argues that the increasing dissemination of CSR and innovations approaches among companies reinforce the mutually supportive and/or complementarities effect, with strategic approaches to CSR and innovation increasingly strengthens companies' ability to draw on their relationships, while the scope of CSR and innovation actions within the companies and their stakeholder relationships become increasingly expanding (incremental) over time. There appears to be existence of three forms of relationships between CSR and innovation: bi-directional, i.e., CSR affects innovation, and innovation, in turn, affects CSR, innovation provides opportunities for CSR and CSR, in turn, provides opportunities for innovation. Ultimately, this mutually supportive and/or complementarities effect, i.e., strategic approaches to CSR and innovation increasingly strengthen companies' ability to draw on their relationships. The paper contributes by exploring how CSR and innovation approaches follow a similar underlying rationale rather than isolated (unrelated) phenomena in the context of companies' quest for survival and reputation. While CSR and innovation research follow different theoretical perspectives, the two concepts are, in fact, both driven by similar considerations.
\end{abstract}

Keywords: Corporate Social Responsibility (CSR), Innovation, Reputation

DOI: $10.7176 / \mathrm{EJBM} / 11-15-01$

Publication date:May $31^{\text {st }} 2019$

\section{Introduction}

Corporate responsibility has both social and environmental dimensions. Corporate social responsibility (CSR) has been discussed in the business literature for decades (see, e.g., Carroll, 1999). Corporate environmental responsibility, a related concept, has increasingly become an issue of concern and has received some research attention (Hart, 1995). In most cases, however, these closely related streams of research have largely been treated separately in empirical research (see, e.g., Midttun, 2007). It has been argued that the impact of social and environmental issues of concern are fundamentally intertwined; hence the need to take a wide view of corporate responsibility by integrating the social and environmental components (Kolk and Van Tulder, 2010). In recent years the CSR concept has gained prominence in the academic literature, joining the mainstream management literature as a legitimate area of inquiry, and has accordingly, evoked heightened interest among scholars and practitioners (Moir, 2001).

The corporate social responsibility (CSR) literature suggests that consumers and other stakeholders usually prefer to associate with companies that endorse socially responsibility practices (Sen and Bhattacharya, 2001). In this respect, some companies have demonstrated through, for example, the establishment of CSR budget which may underpin the argument that CSR is not merely the "right thing to do", but more importantly, "the smart thing to do" (Smith, 2003). The CSR concept largely reflects obligations owe to stakeholders who are either directly or indirectly affected by a firm's activities, and its importance is increasing with particular reference to the activities of multinational enterprises (MNEs) (De Chiara and Spena, 2011). CSR is increasingly attracting companies' attention in their desire for value maximization and reputation. The escalating social and environmental challenges of recent years; including, for example, climate change and neglect of labour rights, are pointers to companies to rethink their processes, products, and/or services, and further, embrace innovation as a crucial factor to corporate success and competiveness (Child and Tsai 2005), and reputation (Fombrun and Riel, 1997).

There are suggestions that to be successful and innovative in recent years, companies have to take into account the social and environmental impact of their activities. This requires that companies challenge their employees to embrace creativity and also collaborate with supply-chain actors in designing and developing new products that take elements of CSR into accounts (Husted and Allen, 2007). Whilst pressure continues to mount on governments 
to provide extensive social services, companies have been challenged to play their part by being more visible in efforts at addressing societal expectations (Sahlin-Andersson, 2006). Many companies have embraced the CSR phenomenon and are contributing in diverse ways to society. Indeed, some companies have even gone a step further by including aspects of CSR themes into their mission, vision and value statements (Pearce and Doh, 2012). The publication of annual reports, for example, has seen new trends such as the inclusion of CSR reports that do not merely address how companies have responded to social and environmental issues of concern, but also some improvement in the extent of transparency by engaging independent external reviewers to audit these reports (Deegan, 2002).

There is a growing awareness that companies' responsibility extend beyond profit-maximization objective to include calls and/or obligations for managing relationships with specific stakeholder groups - shareholders, suppliers, employees, customers, communities and the environment (Waddock et. al., 2002). Stakeholders' expectations of companies have increased in recent years to the extent that large and small, and indigenous and foreign-owned companies find it inescapable but to admit these obligations and to accordingly discharge their corporate social responsibility. Innovation is considered essential for companies' survival and can be positively related to performance (see, e.g., Calantone et. al., 2002; Hill and Rothaermel, 2003). Companies that introduce new ideas to the market have been shown to have better prospects for survival and success than their counterparts that get stuck to existing products ideas and processes (see, e.g., Calantone et. al., 2002; Hill and Rothaermel, 2003). Managing innovation as the basis for survival and growth has received considerable scholarly attention for decades (see, e.g., Burns and Stalker, 1961), and has been shown to positively impact the performance of companies, especially when environmental factors; a key element of CSR, are taken into account (Lyon and Maxwell, 2008).

Evidence suggests that CSR can contribute in achieving shareholder value maximization especially when management strategies such as innovation are taken into account (Husted and Allen, 2007). A company's capabilities with respect to products and processes innovation, for example, are key performance indicators that are taken into account in the definition of companies' product quality, productivity, and image (Easterby-Smith and Prieto, 2008). Despite the large body of research on CSR and innovation, attempts at integrating the two fields of research in the literature has largely not received much research attention (see, e.g., Midttun, 2007); although few studies (see, e.g., MacGregor and Fontrodona, 2008; Husted and Allen, 2007; McWilliams and Siegel, 2001) have sought to explore the link between CSR and innovation, or aspects thereof, without a consensus having been reached. Bansal (2005) and Husted and Allen (2007), in particular, have underscored the need to pay closer attention to the link between CSR practices and innovation strategy of companies.

In this paper, the focus is on CSR and innovation, paying particular attention to their complementarities in the activities of companies and their ability to interact to address the needs and demands of companies' stakeholders, thereby addressing the bias towards the poor interaction between the two streams of CSR literature and innovation literature, and in rethinking companies' CSR and innovation strategies in their quest for survival and reputation (Bansal, 2005; Husted and Allen, 2007; Midttun, 2007). We address the question whether the simultaneous pursuit of CSR and innovation is, in fact, a realistic and/or supportive ambition or rather isolated (unrelated) phenomena in the context of companies' CSR and innovation actions in their quest for survival and reputation. Using stakeholder theory as a lens, in turn, drawing from organisational legitimacy theory and organisational learning theory, this paper argues that the increasing attention on CSR and innovation and dissemination of CSR and innovation approaches among companies results in a mutually supportive and/or complementarities effect, with strategic approaches increasingly strengthen companies' ability to draw on their relationships, while the scope of actions within the companies and their stakeholder relationships become increasingly expanding (incremental) over time. It follows that this mutually supportive and/or complementarities effect, in turn, reinforces the positive relationship between companies' CSR and innovation activities. Consequently, it also results in the increased application of innovation approaches to CSR, focussing on integration and consistency of approaches rather than isolated (unrelated) responsiveness to companies' CSR and innovation actions.

The remainder of this paper is structured as follows: the next section focusses on review of the CSR literature and innovation literature to highlight the vast range of definitions that have emerged, some of which differ substantially when it comes to the issues they address and/or the modus operandi they prescribe, and the challenges this poses to companies' CSR and innovation actions. Subsequently, an overview of conceptual and empirical studies on CSR and innovation approaches is presented with particular emphasis on scholarly work linked to the integration of CSR and innovation. In the following section, the theoretical framework of this study, which draws on the stakeholder literature as theoretical lens, organisational legitimacy theory and organisational learning theory as lenses through which the relationship between CSR on the one hand, and innovation on the other hand are analysed. Using examples of CSR and innovation initiatives, guidelines and tools, we provide evidence for the existence of a mutually supportive and/or complementarities effect as one of the defining characteristic of the relationship between approaches to CSR and innovation. The paper proceeds with a discussion of this mutually 
supportive and/or complementarities effect in the context of companies quest for survival and reputation. The paper concludes that there appears to be existence of three forms of relationships between CSR and innovation: bi-directional, i.e., CSR affects innovation, and innovation, in turn, affects CSR, innovation provides opportunities for CSR and CSR, in turn, provides opportunities for innovation.

\section{Literature Review}

Defining corporate social responsibility (CSR)

In the literature, CSR has been given different definitions and/or interpretations, presumably because of the many conflicting objectives that companies seek to achieve by undertaking CSR activities. Although no consensus has been reached on a commonly accepted definition of CSR (see, e.g., Garriga and Mele, 2004; McWilliams and Siegel, 2001), a common theme in most definitions of CSR is the provision that the activities of firms can be considered to be CSR in nature when the "actions appear [...] to further some social good, beyond the interests of the firm and that which is required by law" (McWilliams et. al., 2006, p. 117). The lack of consensus on the boundaries of CSR had long been envisaged. It was over 40 years ago that Votaw wrote that:

"Corporate social responsibility means something, but not always the same thing to everybody. To some it conveys the idea of legal responsibility or liability; to others, it means socially responsible behaviour in the ethical sense; to still others, the meaning transmitted is that of 'responsible for' in a causal mode; many simply equate it with a charitable contribution; some take it to mean socially conscious; many of those who embrace it most fervently see it as a mere synonym for legitimacy in the context of belonging or being proper or valid; a few see a sort of fiduciary duty imposing higher standards of behaviour on businessmen than on citizens at large" (Votaw, 1972, p. 25).

For the purpose of this paper, CSR is defined as firms actions that are primarily driven by the notion that business and society are intertwined, and that the profit-maximization (economic) objective of the firm should be purposefully pursued alongside the fulfilment of implied responsibilities to the broader society (stakeholders) within which the firm operates. In effect, the pursuit of economic value and social value can be achieved concurrently and can be mutually reinforcing.

\section{Defining innovation}

A vast range of definitions and/or interpretations has emerged in relation to innovation, innovation types and innovativeness, and general consensus on some essential elements appears to have evolved in the literature, namely, innovativeness, radical, really-new, incremental, and continuous (Garcia and Calantone, 2002). Nonetheless, this has led to ambiguity in the way the terms 'innovation' and innovativeness' are used in the literature. Terms such as "radical", "really-new", "incremental", and "continuous" have often been used to characterize 'innovation' and 'innovativeness' (Garcia and Calantone, 2002). Innovation can be defined as the effective exploitation of new ideas, using a foundation of existing knowledge to create new products and services, or to develop existing ones. Daft (1982) points out that innovation is the adoption of new systems, policies, programmes, processes, products or services, which can be internally or externally generated. The 'innovation' phenomenon is thus strongly associated with change in the broader sense. Damanpour (1996, p. 694), provides a detailed definition of innovation, which is much quoted in the literature: "innovation is conceived as a means of changing an organization, either as a response to changes in the external environment or as a pre-emptive action to influence the environment". Other definitions of innovation appear to be influenced by the disciplinary orientation of the researcher or researchers. In the field of knowledge management, for example, the focus of innovation appears to emphasize the relevance of 'knowledge' for innovation purposes (see, e.g., Baregheh et. al., 2009). This paper follows Baregheh et. al. (2009) and defines innovation as "the exploitation of new knowledge through the recombination of existing knowledge and the adoption of new knowledge, external to the firm in order to facilitate the creation of improved value and sustaining the firm's competitive advantage".

McGregor and Fontrodona (2008) explore the fit or space between CSR and innovation, based on the "RESPONSE project" - a 15 month study which involved 60 SMEs throughout Europe. The study sought to investigate the bi-directional, that is, the effect of CSR on innovation and vice-versa. Their findings suggest that CSR-driven innovation is aimed at products and services that possess some social purpose, while innovationdriven CSR, on the other hand, seems to be more aligned with the motive of creating social processes and appears to be driven primarily by value; that is, an innovation-centric approach to CSR that appears to be more closely linked to the "employees", "supply-chain", and "customers" categories of CSR. Similarly, McWilliams and Siegel (2000) in an attempt to build upon the conventional model that describes the relationship between CSR and a firm's performance, argue about the limitations of the conventional model on the grounds that it does not include some notable variables such as the intensity of R\&D investment by a firm. Given that R\&D investments form part of a firm's differentiation strategy, they expected a positive correlation between CSR and R\&D activities of a firm.

McWilliams and Siegel (2001, p. 119) argue in favour of a correlation between R\&D and CSR, by suggesting that many aspects of CSR create either a process or product innovation or both. Arguing from a theory of the firm 
perspective, they suggest that CSR can be viewed as a form of investment, and a means by which investment in CSR can be assessed is through product differentiation. In effect, differentiating through the use of CSR activities such as recycled products, or organic pest control may also include investment in R\&D. Consequently, R\&D investments may result in both CSR-related process and product innovations, which are each valued by some customers. Midttun (2007) also explores the interplay between CSR and innovation by questioning the premise, often underlying EU communications, that the two agendas are in general mutually supportive. The findings show the difficulties of assuming that innovation policy and corporate responsibility policy can easily be mutually supportive. The paper argues that while the assumptions of compatibility and synergy may be reasonable for some types of innovation, and also some types of corporate responsibility, it becomes difficult to place the same argument in a general perspective. A key finding calls for differentiating between complementary static and dynamic views. The paper concludes that while much of the innovation literature appears dynamic in nature, much of the corporate responsibility literature has traditional inclination and seems to have been given a static interpretation. To summarize, this brief literature review is intended to facilitate the reader's understanding, by highlighting inconsistencies in the interpretation of both CSR and innovation, and more importantly, to recognize some of the major limits, associated with efforts, aimed at integrating CSR and innovation in the literature.

\section{Theoretical framework}

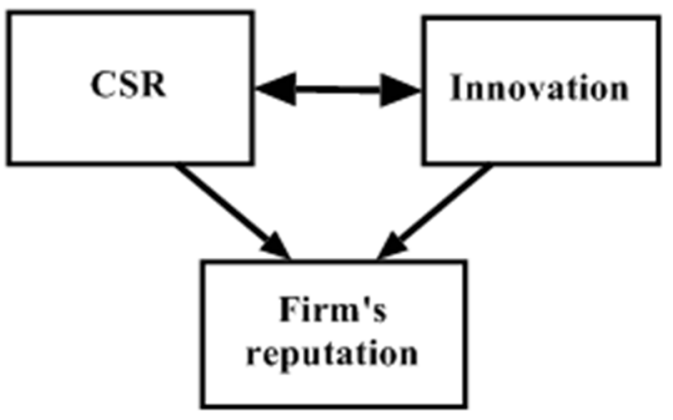

Figure 1. A model of the relationship between CSR and innovation

\section{CSR and innovation relationship}

According to Figure 1, a firm's CSR initiatives and innovative activities impact and/or complement each other and together, determine and/or influence the firm's reputation. In this paper, it is suggested that a firm's ability to identify and draws on the complementarities between its CSR actions and innovation activities will depend on the network of exchange relationships established with the firm's constituents, which in turn can enhance the firm's reputation, in as much as the firm itself effectively uses its own firm-specific capabilities to build its reputation. According to Vilanova et. al. (2009), a company's capabilities in the area of product and process innovation are important performance indicators that should be taken into account in defining its product quality, productivity, and image. Husted and Allen (2007) suggest that a firm's CSR activities can play an important role in creating value for the firm and its shareholders, especially when attempts at integrating innovation alongside are given equal attention.

\section{Bi-directional nature of CSR and innovation relationship}

As has been shown in previous studies (see, e.g., Bansal, 2005; McWilliams and Siegel, 2000) the relationship between a company's research and development (R\&D) activities and CSR actions can be bi-directional in nature. Thus, on the one hand, a firm can use its CSR initiatives as the basis to foster product and process innovation; and on the other hand, a firm that has the capability for continuous innovation, can leverage that same resource in other aspects of its operations, for example, the development and implementation of its CSR strategy (Husted and Allen 2007).

\section{Ability of innovation to provide opportunities for CSR}

The object of innovation, according to Paap and Katz (2004) is usually conceived to include things (products and services), changes in the way products and services are created and delivered (processes), organization, transactions, business model, and management processes and style. Essentially, the object of innovation provides numerous opportunities such as developing innovative products design solutions that take account of environmentrelated issues, (e.g. design for re-use, and design for environment); social responsible design that takes an integrative approach to existing design initiatives, (e.g. social and/or inclusive design); and ethical manufacture that facilitate the inclusion of CSR into a firm's processes. Increasingly, from a CSR point of view as posited by MacGregor and Fontrodona (2008), a firm should endeavour to innovate its actions and processes by paying 
attention not only to the demand for socially responsible products, but also at the same time being mindful of the implications of social responsibility of the actions and/or activities of actors across the firm's supply.

\section{Ability of CSR to provide opportunities for innovation}

Strategic management research (see, e.g., Husted and Allen, 2007) suggests that a firm's CSR practices has the potential to provide possibilities for innovation. In some firms, for example, CSR practices may lead to innovation through the adoption of social, environmental or sustainable dimensions that contribute in creating new ways of working, new products and/or services, new and/or efficient processes, and new markets for such firms. The adoption of CSR practices, it is asserted, can serve as the starting point for proactive innovation activities, especially for firms that want to improve their position in their respective markets but are reluctant to take the risk associated with innovation. This approach in particular has tremendous implications for firms that have the capability to innovate, but are generally not prepared to take the risk that is associated with experimentation and/or innovativeness (MacGregor and Fontrodona 2008).

Firm's reputation

A firm's reputation, arising from its capabilities to draw on the complementarities inherent in its CSR and innovative activities, should be addressed by considering three dimensions: stakeholders, legitimacy and learning as shown in Figure 2.

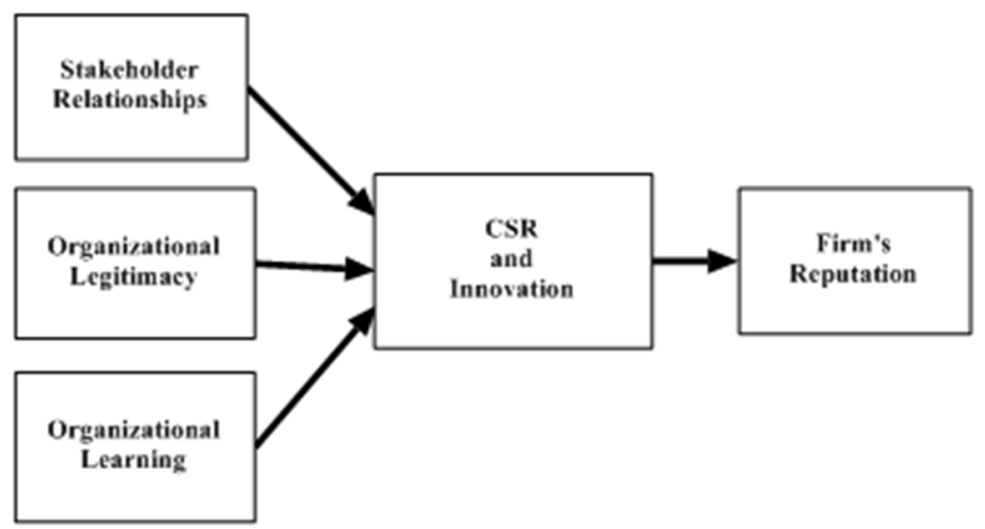

Figure 2. Operational framework affecting a firm's reputation

It has long been argued by organizational scholars that a good reputation provides numerous benefits such as lower costs and the ability to request premium prices (see, e.g., Rhee and Haunschild, 2006), and also more positive performance (see, e.g., Roberts and Dowling, 2002). Further, a favourable reputation has been shown to have an impact on the willingness of suppliers and buyers, for instance, to transact with the focal firm (Fombrun and Shanley 1990). Positive differentiation strategies that have the potential to enhance a firm's reputation can contribute in making a firm effective.

\section{Stakeholder relationships}

Essentially, as a firm engages in CSR activities, stakeholders (e.g., consumers, community, and regulators) develop expectations of the firm's commitment, and are likely to impose this expectation on the firm (Hillman and Keim, 2001). A firm that engages in CSR actions is likely to develop a reputation for social responsible behaviour; a breach of which can result in negative reputation spillovers for the firm. It therefore follows that a high CSR reputation (derived from prior CSR activities), is expected to influence the willingness of the firm to engage in present and future CSR activities. Through a firm's interaction with key stakeholders from whom its draws complementary capabilities and resources, it is likely that the firm will become more efficient with its use of resources devoted to CSR, thus enhancing the firm's ability to derive the most benefits from these activities. Consequently, the present level of reputation, gained though CSR activities, is expected to influence subsequent CSR activities by, for example, guiding the scalability of a firm's CSR actions through integrating innovation into CSR activities and vice versa.

\section{Organisational legitimacy}

It is imperative for a firm to gain approval of its actions based on stakeholders' evaluations. As argued elsewhere (see, e.g., Rindova et. al., 2006), legitimacy and reputation are key intangible assets that firms rely on to enhance their performance. A firm that is legitimate is likely to be perceived as "more worthy, [...] more meaningful, more predictable, and more trustworthy” than a firm that is illegitimate (Suchman, 1995, p. 575). Hence, a firm's concern for society demonstrated through its CSR activities, may facilitate its ability to build mutually beneficial exchange 
relationships with stakeholders by adhering to societal norms, and at the same time fulfilling promises and expectations of the different stakeholder groups.

\section{Organizational learning}

Institutional settings in which a firm is an important actor can facilitate learning that leads to the creation and dissemination of value-producing knowledge (see, e.g., Grant, 1996; Nahapiet and Ghoshal, 1998) In such institutional settings, a firm would have repeated dealings with actors such as customers, suppliers, and the community that can generate reputational capital and trust among the actors. Through relational rather than transactional interactions and/or cooperation, a firm can expand the set of value creating exchanges that cannot be easily duplicated by competitors. Hence, a firm constrained by its deficient internal capabilities to learn in order to improve performance (e.g., improving its innovation capabilities), may engage in mutually beneficial exchange relationship, through adopting different interaction strategies to access any additional resources and capabilities. This leads to the first proposition:

P1. A company's ability to gain legitimacy and engage in mutual beneficial interaction with stakeholders will enhance its reputation.

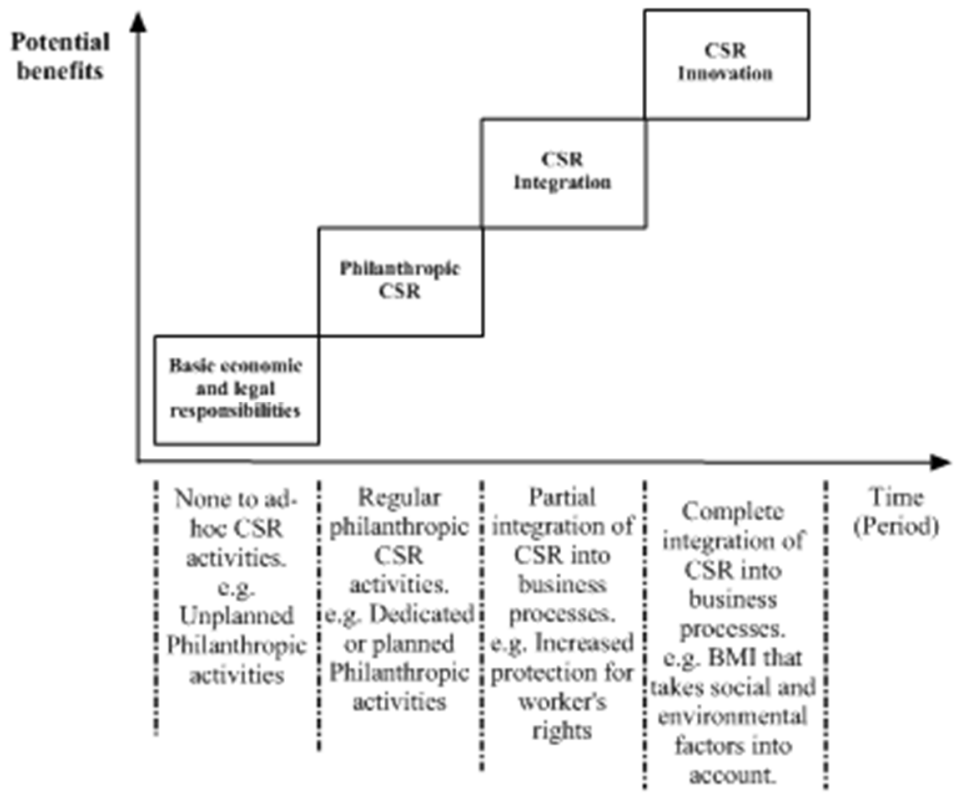

Figure 3. A model of innovation-driven incremental CSR

\section{Discussion}

As has been argued above, the simultaneous pursuit of CSR and innovation, might be a realistic expectation for companies that desire for survival and reputation. Through their CSR actions companies may be captured as "citizens" that provide some benefits to society and the environment, and also succeed in improving their reputation and competitiveness (Husted and Allen, 2007; Porter and Kramer, 2002) by adopting differentiation strategy (McWilliams and Siegel, 2001). In a more dynamic environment, a company's CSR activities should strategically shape its identity. Through a company's CSR actions, attention is mainly focused on three key drivers: product innovation, environmental concerns, and community involvement (Keller and Aaker, 1998). This suggests that the process of scaling-up a company's CSR activities should be coupled with the adoption of incremental and other models of innovation that may contribute in enhancing the company's reputation. Essentially, a gradual shift of CSR emphasis from ad-hoc and/or unplanned CSR orientation to progressive and/or incremental CSR orientation suggests the potential for companies to introduce CSR elements into their innovation activities. The dynamic character of innovation, similar to CSR, and generally described in terms of change processes, including changes to existing products and processes, should facilitate attempts at integrating CSR and innovation. This leads to our second proposition:

\section{P2. Adoption of CSR serves as the starting point for a proactive innovation process.}

The response of companies to CSR activities as suggested by MacGregor and Fontrodona (2008) typically ranges 
from inactive through reactive to interactive and finally proactive. This conceptual paper argues that a company's attempt at integrating its CSR and innovation activities can be modelled along the following path:

\section{Inactive response to CSR}

For some companies, the initial reaction to CSR might be inactive; that is, non-involvement in CSR activities as their focus remains solely on the pursuit of economic responsibilities and by extension, adhering to the required legal responsibilities. These companies, however, may deem it appropriate to make unplanned and/or philanthropic activities. The potential benefit of inactive response to CSR can be very low, and might be due to the relatively irregular nature of involvement in CSR activities. This corresponds to basic economic and legal responsibilities in Figure 3.

\section{Reactive response to CSR}

Next, a company progresses from an initial inactive posture to a reactive response to CSR activities; i.e., involvement in CSR activities through a 'philanthropic' orientation, as its focus does not remain solely on the pursuit of economic and legal responsibilities, but also engages in regular and/or planned philanthropic CSR activities. The potential benefit of reactive posture to CSR can be low, and may be largely due to the irregular nature of involvement in CSR activities. Reactive response to CSR provides opportunity for experimenting with and/or introducing new product to the market through donation and might also serve as a platform for responding to new legislation. This corresponds to philanthropic CSR in Figure 3.

\section{Interactive response to $C S R$}

From a reactive posture to CSR, a company next progresses to interactive response to CSR activities. This represents a deeper involvement in CSR activities through a partial adoption and integration of CSR principles into the company's business processes. The potential benefit of interactive approach to CSR can be relatively high, and might be attributable to the relatively proactive orientation to CSR that results in the need for the company to continuously innovate its business processes. This corresponds to 'CSR integration' in Figure 3.

\section{Proactive response to $C S R$}

Ultimately, from an interactive approach to CSR, a company next progresses to proactive approach to CSR activities. This represents a much deeper involvement in CSR activities through a complete adoption and integration of CSR principles into the company's business processes. The potential benefit of proactive approach to CSR can be very high, and might be explained in terms of the forward-looking and anticipatory orientation to CSR that results in the need for the company to continuously innovate its business processes. This corresponds to CSR innovation in Figure 3. Companies that are proactive are usually innovative and are characterized by a tendency to continuously rethink their business processes in order to identify areas for further improvement. This leads to our third proposition:

\section{P3. Companies that are proactive tend to outperform their rivals based on their ability to innovate.}

\section{Conclusion}

This paper sought to explore how CSR relates to innovation and their effect on building a company's reputation. This paper argues that the increasing attention on CSR and innovation and dissemination of CSR and innovation approaches among companies results in a mutually supportive and/or complementarities effect, with strategic approaches increasingly strengthen companies' ability to draw on their relationships, while the scope of actions within the companies and their stakeholder relationships become increasingly expanding (incremental) over time. The paper argues that for CSR and innovation activities to complement each other, a dynamic and integrative approach need to be adopted in their respective design and implementation. Also argued in this paper is that as companies interact with their stakeholders, they learn and become capable of innovating their activities; CSR activities inclusive, either in response to current opportunities and/or challenges, or in anticipation of future opportunities and/or challenges. A company's legitimacy and its relationships with stakeholders, and how and what it learns in its interaction networks, will enhance its reputation and improve its capabilities with regards to the design and implementation of CSR and innovation activities. Attempts at integrating CSR into a company's business processes starting from ad-hoc CSR activities through to CSR innovation highlights a mutually supportive and/or complementarities between CSR and innovation, suggesting that both CSR and innovation can co-evolve in a company and complement each other. The paper concludes that there appears to be existence of three forms of relationships between CSR and innovation: bi-directional, i.e., CSR affects innovation, and innovation, in turn, affects CSR, innovation provides opportunities for CSR and CSR, in turn, provides opportunities for innovation. Ultimately, this mutually supportive and/or complementarities effect, i.e., strategic approaches to CSR and innovation increasingly strengthen companies' ability to draw on their relationships. The paper contributes by 
exploring how CSR and innovation approaches follow a similar underlying rationale rather than isolated (unrelated) phenomena in the context of companies' quest for survival and reputation. While CSR and innovation research follow different theoretical perspectives, the two concepts are, in fact, both driven by similar considerations.

\section{References}

Bansal, P. (2005). "Evolving sustainably: a longitudinal study of corporate sustainable development." Strategic management journal 26(3): 197-218.

Baregheh, A., Rowley, J. and Sambrook, S. (2009). "Towards a multidisciplinary definition of innovation." Management decision 47(8): 1323-1339.

Burns, T. E. and G. M. Stalker (1961). "The management of innovation." University of Illinois at UrbanaChampaign's Academy for Entrepreneurial Leadership Historical Research Reference in Entrepreneurship.

Calantone, R. J., Cavusgil, S.T. and Zhao, Y. (2002). "Learning orientation, firm innovation capability, and firm performance." Industrial marketing management 31(6): 515-524.

Carroll, A. B. (1999). "Corporate social responsibility evolution of a definitional construct." Business \& society 38(3): 268-295

Child, J. and T. Tsai (2005). "The Dynamic Between Firms' Environmental Strategies and Institutional Constraints in Emerging Economies: Evidence from China and Taiwan." Journal of management studies 42(1): 95-125.

Daft, R. (1982). "A dual-core model of organizational innovation." Academy of management journal.

Damanpour, F. (1996). "Organizational complexity and innovation: developing and testing multiple contingency models." Management science 42(5): 693-716.

De Chiara, A. and T. R. Spena (2011). "CSR strategy in multinational firms: focus on human resources, suppliers and community." Journal of Global Responsibility 2(1): 60-74.

Deegan, C. (2002). "Introduction: the legitimising effect of social and environmental disclosures-a theoretical foundation." Accounting, Auditing \& Accountability Journal 15(3): 282-311.

Easterby-Smith, M. and I. M. Prieto (2008). "Dynamic Capabilities and Knowledge Management: an Integrative Role for Learning?." British Journal of Management 19(3): 235-249.

Fombrun, C. and C. B. M. Riel (1997). "The reputational landscape." Corporate reputation review: 1-16.

Fombrun, C. and M. Shanley (1990). "What's in a name? Reputation building and corporate strategy." Academy of management journal 33(2): 233-258.

Garcia, R. and R. Calantone (2002). "A critical look at technological innovation typology and innovativeness terminology: a literature review." Journal of Product Innovation Management 19(2): 110-132.

Grant, R. M. (1996). "Toward a knowledge-based theory of the firm." Strategic management journal 17: 109-122.

Hart, S. L. (1995). "A natural-resource-based view of the firm." Academy of management review 20(4): 986-1014.

Hill, C. W. and F. T. Rothaermel (2003). "The performance of incumbent firms in the face of radical technological innovation." Academy of management review 28(2): 257-274.

Hillman, A. J. and G. D. Keim (2001). "Shareholder value, stakeholder management, and social issues: what's the bottom line?" Strategic management journal 22(2): 125-139.

Husted, B. W. and D. B. Allen (2007). "Corporate social strategy in multinational enterprises: Antecedents and value creation." Journal of Business Ethics 74(4): 345-361.

Keller, K. L. and D. A. Aaker (1998). "The impact of corporate marketing on a company's brand extensions." Corporate reputation review 1(4): 356-378.

Kolk, A. and R. Van Tulder (2010). "International business, corporate social responsibility and sustainable development." International Business Review 19(2): 119-125.

Lyon, T. P. and J. W. Maxwell (2008). "Corporate social responsibility and the environment: A theoretical perspective." Review of environmental economics and policy 2(2): 240-260.

MacGregor, S. P. and J. Fontrodona (2008). "Exploring the fit between CSR and innovation."

McWilliams, A. and D. Siegel (2000). "Corporate social responsibility and financial performance: correlation or misspecification?" Strategic management journal 21(5): 603-609.

McWilliams, A. and Siegel, D. (2001). "Corporate social responsibility: A theory of the firm perspective." Academy of management review 26(1): 117-127.

McWilliams, A., Siegel, D., Wright, P. M. (2006). "Corporate social responsibility: Strategic implications." Journal of management studies 43(1): 1-18.

Midttun, A. (2007). "Towards a dynamic reinterpretation of C (S) R: are corporate responsibility and innovation compatible or contradictory?" Corporate Governance 7(4): 401-413.

Moir, L. (2001). "What do we mean by corporate social responsibility?" Corporate Governance 1(2): 16-22.

Nahapiet, J. and S. Ghoshal (1998). "Social capital, intellectual capital, and the organizational advantage." Academy of management review 23(2): 242-266.

Paap, J. and R. Katz (2004). "Anticipating disruptive innovation." Research-Technology Management 47(5): 1322. 
Pearce, J. and J. P. Doh (2012). "The high impact of collaborative social initiatives." Sloan Management Review 46(2).

Porter, M. E. and M. R. Kramer (2002). "The competitive advantage of corporate philanthropy."

Rhee, M. and P. R. Haunschild (2006). "The liability of good reputation: A study of product recalls in the US automobile industry." Organization science 17(1): 101-117.

Rindova, V. P., Pollock, T. G., Hayward, M. L. (2006). "Celebrity firms: The social construction of market popularity." Academy of management review 31(1): 50-71.

Roberts, P. W. and G. R. Dowling (2002). "Corporate reputation and sustained superior financial performance." Strategic management journal 23(12): 1077-1093.

Sahlin-Andersson, K. (2006). "Corporate social responsibility: a trend and a movement, but of what and for what?" Corporate Governance 6(5): 595-608.

Sen, S. and C. B. Bhattacharya (2001). "Does doing good always lead to doing better? Consumer reactions to corporate social responsibility." Journal of marketing Research 38(2): 225-243.

Smith, N. C. (2003). "Corporate social responsibility: not whether, but how." Center for Marketing Working Paper (03-701).

Suchman, M. C. (1995). "Managing legitimacy: Strategic and institutional approaches." Academy of management review 20(3): 571-610.

Vilanova, M., Lozano, J. M., and Arenas, D. (2009). "Exploring the nature of the relationship between CSR and competitiveness." Journal of Business Ethics 87(1): 57-69.

Waddock, S. A., Bodwell, C. and Graves, S.B. (2002). "Responsibility: The new business imperative." The Academy of Management Executive 16(2): 132-148.

\begin{abstract}
About the author
Gideon Jojo Amos is a PhD student at the Center for Innovation, Entrepreneurship and Learning (CIEL) Research, Halmstad University, Sweden. Previously, he worked in the Finance Department of a large MNE subsidiary headquartered in South Africa, in Ghana, prior to pursuing MSc. International Business at the School of Business, Economics, and Law, University of Gothenburg, Gothenburg, Sweden. He is currently a lecturer in Management and International Business at the University of Education, Winneba, Ghana. His research interest lies around issues of business ethics, corporate social responsibility (CSR), and sustainability-related practices of multinational enterprises (MNEs) in developing-countries. His Bachelor's degree in Commerce and Master's degree in International Business provide him with a better understanding of activities of MNEs in developing-countries.
\end{abstract}

